land beach. In summer 1981, almost two years after the replenishment commenced, the densities on the Texel beach were back to normal. Juvenile organisms reappeared in autumn 1980.

Conclusions. Depending on the way the works are performed, the benthic fauna can be almost completely destroyed. However it is not a rare fauna and recovery is almost complete after some years. Locally, predators will find less food and will have to move further along the beach.

In relation to the beneficial effects such as the preservation of a natural coastline, and the conservation of rare and valuable dune vegetation, beach replenishment can be considered a recommendable method if the sand is extracted from a suitable place.

This synopsis is based on a report entitled 'De effecten van zandsuppletie op de fauna van het strand van Texel en Ameland', Research Institute for Nature Management, 1983. ii +12 pp., 5 figs., 1 table, 9 refs. Dutch.

Available as paper copy (order R012P, $f 3.70$ including postage) or microfiche (order R012 M, f 12.50 including postage) at: NARD, clo Pudoc, P.O. Box 4, 6700 AA Wageningen, Netherlands (telex $45015 \mathrm{blhwg} \mathrm{hl}$ ).

\title{
Development and growth of trees in small-scale regeneration
}

L. J. G. Koks and R. P. Leersnijder (Department of Silviculture, Agricultural University, P.O Box 342, $6700 \mathrm{AH}$ Wageningen, Netherlands)

Accepted: 5 June 1984

Abstract. A graphical and mathematical model was developed to describe natural or artificial regeneration of trees in systems of small-scale silviculture. The pattern of growth was particularly influenced by light conditions and by root competition at the edges of the clearing.

Key-words: growth rate; small-scale regeneration; root competition; competition; small-scale forest management; graphical model.

Introduction. Small-scale forest management is defined as management in a system with regeneration units under a canopy gap which has a diameter of not more than three times the tree height. The microclimate so remains the predominant factor. The aim of management is wood production and maintenance of the forest as a 
community of plants and animals. Some properties of forest edges were applied in the design of a model for small-scale regeneration.

The graphical model. A graphical model was designed to describe the transformation from large-scale to small-scale forest management (e.g. Knuchel, 1923). It is important for the design of a graphical model to know the starting situation and the situation that we want to create. We must then know:

- age distribution, species composition in the stand and the part of the forest to be transformed;

- site class or 'S value' of the tree species (Schütz \& van Tol, 1982);

- soil properties;

- ratio between tree height and crown diameter;

- quality of stem and crown of the trees;

- sort of situation we wish to create;

- area to be transformed and the time allowed for transformation.

These factors are supposed to be known. There are also some unknowns, to which values have to be attributed for the graphical model:

- the occurrence of natural regeneration;

- development and growth rate of trees in small-scale regeneration dealt with here;

- competition between different tree species.

Development and growth rate of trees in small-scale regeneration. The growth of young trees near the old stand or near old trees is defined by competition with those old trees for light, water and nutrients, as well as by site quality and tree species. This leads to the hypothesis of 'places with maximum and minimum growth potential'. The concentric form of the root growth around an old tree sometimes makes regeneration impossible within a certain distance of the old tree. After clear-cutting there will be a forest border. The root space that comes free will be used by border trees but also by more distant trees that send out new roots to it (Oldeman, 1980). The total reaction of the forest edge to the open space results in a minimum distance to this edge at which growth is possible. From this minimum distance, the conditions

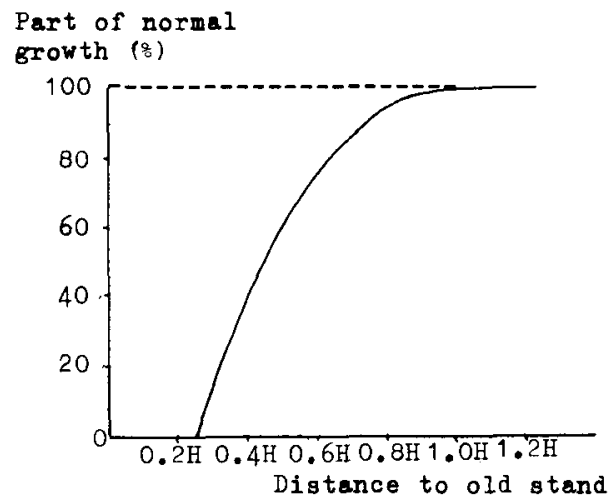

156
Fig. 1. Relationship between expected growth and distance to the old stand. 


\section{J. G. KOKS AND R. P. LEERSNIJDER}

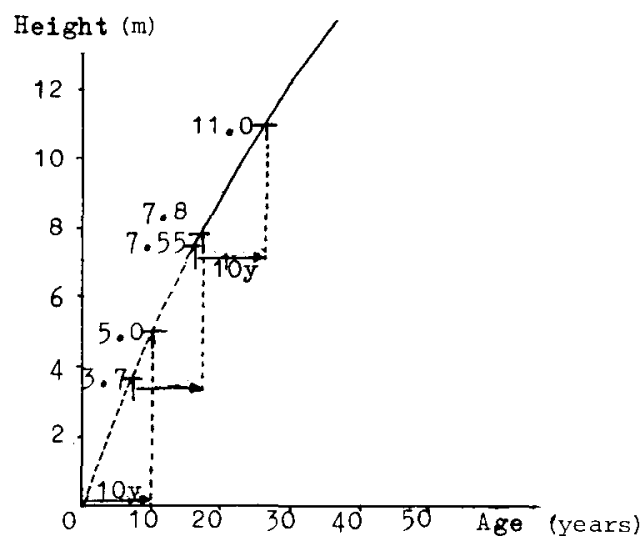

Fig. 2. Comment to the development of regeneration as constructed in Fig. 3 (curve for height growth under large-scale conditions of Pinus sylvestris, $\mathrm{S}=26 \mathrm{~m}$; after Schütz \& van Tol, 1982).

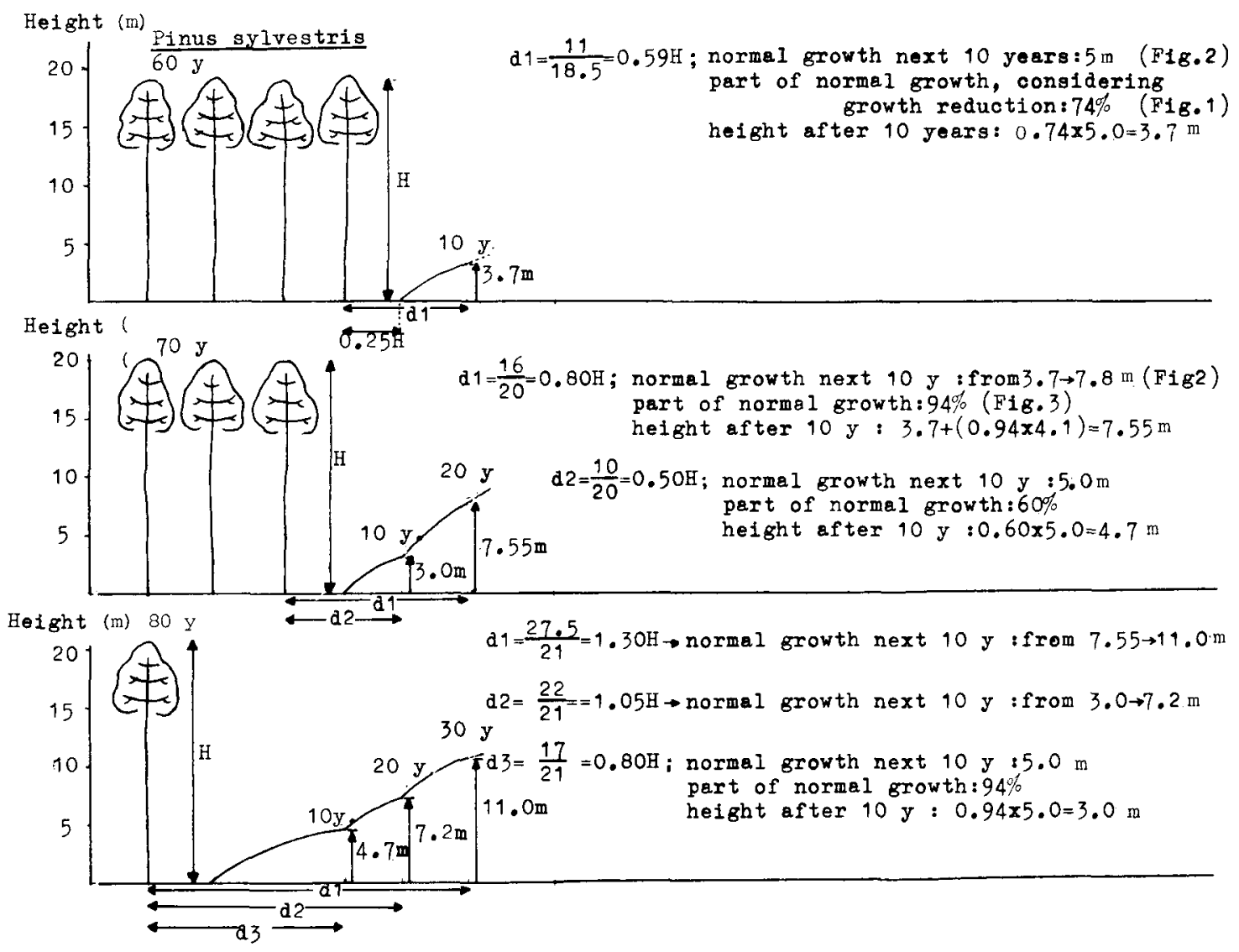

Fig. 3. Development of regeneration of Pinus sylvestris when gradually cutting the border trees.

Neth. J. agric. Sci. 32 (1984) 


\section{J. G. KOKS AND R. P. LEERSNIJDER}

for growth gradually become better and height growth reaches a maximum. For the time being, we are assuming that maximum growth is the same as growth in largescale forest management. The minimum and maximum distance are expressed as follows:

minimum distance $=a \cdot H$

maximum distance $=b \cdot H$

where $a$ and $b$ are constants, and $H$ is the border tree height.

The degree to which growth rate is restrained between the places of minimum and maximum growth is shown in Fig. 1. The form of the curve and the places of minimum and maximum growth depend on tree species, site quality and the diameter of the gap in the canopy. With small gaps, more forest edges play a role in the competition, so that growth is more delayed. In Fig. 2 and 3, the calculation of height growth of the saplings is represented for a situation of successive old-border cuttings.

When shelterwood systems are used, the saplings receive more diffuse light and have less root competition problems. Differences between areas of minimum and maximum growth fade. For the time being, the reduction in regenerative growth in shelterwood systems seems best defined by the average shading, represented as the percentage closure of the canopy.

\section{References}

Knuchel, H., 1923. Ueber die Anpassung der Betriebseinrichtung an die heutige waldbauliche Verhältnisse. Schweizerische Zeitschrift für Forstwesen.

Oldeman, R. A. A., 1980. Grondslagen van de bosteelt. Collegedictaat. Vakgroep Bosteelt, Landbouwhogeschool Wageningen, $202 \mathrm{pp}$.

Schütz, P. R. \& G. van Tol, 1982. Aanleg en beheer van bos en beplantingen. Pudoc, Wageningen, 504 pp.

This synopsis is based on a M. Sc. thesis entitled 'Van grootschalig naar kleinschalig bosbeheer - een eerste aanzet', Departments of Silviculture and Forest Management, Agricultural University, Wageningen, 1984. v+160 pp., figs., tables, appendices, 98 refs. Dutch.

Available as paper copy (order R013P, $f 30$ including postage) or microfiches (order R013M, f 17.50 including postage) at: NARD, clo Pudoc, P.O. Box 4, 6700 AA Wageningen, Netherlands (telex $45015 \mathrm{blhwg} \mathrm{nl}$ ). 